\title{
Effect of Strength Enhancement of Soil Treated with Environment-Friendly Calcium Carbonate Powder
}

\author{
Kyungho Park, Sangju Jun, and Daehyeon Kim \\ Department of Civil Engineering, Chosun University, Gwangju 501-759, Republic of Korea \\ Correspondence should be addressed to Daehyeon Kim; dkimgeo@chosun.ac.kr
}

Received 30 August 2013; Accepted 1 December 2013; Published 4 February 2014

Academic Editors: E. Lui and İ. B. Topçu

Copyright ( 2014 Kyungho Park et al. This is an open access article distributed under the Creative Commons Attribution License, which permits unrestricted use, distribution, and reproduction in any medium, provided the original work is properly cited.

\begin{abstract}
This study aims to investigate the effects of the strength improvement of soft ground (sand) by producing calcium carbonate powder through microbial reactions. To analyze the cementation effect of calcium carbonate produced through microbial reaction for different weight ratios, four different types of specimens (untreated, calcium carbonate, cement, and calcium carbonate + cement) with different weight ratios $(2 \%, 4 \%, 6 \%$, and $8 \%)$ were produced and cured for a period of 3 days, 7 days, 14 days, 21 days, and 28 days to test them. The uniaxial compression strength of specimens was measured, and the components in the specimen depending on the curing period were analyzed by means of XRD analysis. The result revealed that higher weight ratios and longer curing period contributed to increased strength of calcium carbonate, cement, and calcium carbonate + cement specimens. The calcium carbonate and the calcium carbonate + cement specimens in the same condition showed the tendency of decreased strength approximately 3 times and two times in comparison with the $8 \%$ cement specimens cured for 28 days, but the tendency of increased strength was approximately 4 times and 6 times in comparison with the untreated specimen.
\end{abstract}

\section{Introduction}

1.1. Background and Objective. Recent increasing cost of raw materials, scarcity of natural materials, and lack of construction materials result in difficulty in developing the construction industry. Fast industrial development contributes to qualitative and quantitative expansion of the national key industry, so Korea experiences difficulty in securing sites in comparison with other countries with large land areas. This leads to Korea's interest in methods of improving soft ground of loose sandy soil or weak silt which has not been considered as a construction site, for efficient use of land. Many construction companies have taken a lot of overseas orders from Middle East countries to work there, and it is thus needed to develop a new method of or new material for improving soft ground.

The Korea Cement Association (2005) says that the volume of cement produced in Korea in 2006 amounts to approximately 48 million tons which is the 7 th place in the global volume of produced cement, and carbon dioxide discharged in producing 1 ton of cement is approximately 0.9 tons. Because carbon dioxide discharged through cement is a major cause of greenhouse gas, various studies are currently underway to develop substitutes for reducing cement to address the environmental issue.

In this study, the effect of the strength improvement of soft ground was analyzed when calcium carbonate produced by microbes was applied to loose sandy soil which is weak ground. To this end, the calcium carbonate was produced as powder like cement to compare it with cement. For analyzing and comparing their applicability with cement, calcium carbonate + cement specimens were produced to analyze their strength through the uniaxial compression test after curing them for 3 days, 7 days, 14 days, 21 days, and 28 days. The XRD analysis was carried out in order to examine chemical reaction and to analyze components of each specimen depending on longer curing period.

1.2. Previous Studies. Various substitutes have been studied for reducing consumed cement. Some Korean and overseas researchers have studied how to use cement created through biological and chemical reactions of $B$. pasteurii (KCTC 3558) which is one type of numerous microbes under the ground to 
cement soft ground Kim et al., [1], [2-8], K. H. Park et al., [9], K. H. Park and D. H. Park [3, 10].

Kim et al. [1] are the first Korean researchers who have studied how to use microbes in order to enhance the strength of soft ground. They developed a method of increasing precipitation of cement by means of the microbial condition of high concentration. They now own a patent of microbial cementation registered in the Korean Intellectual Patent Office and titled "Method of Cementing Soft Ground by Using Microbes" [11]. Microbial cementation of soft ground was identified through a test of mixing an untreated specimen, a high concentration-treated specimen, and a normal concentration-treated specimen [12].

Park et al. [2] intended to cement the ground by using a plant extract with a component of urease to precipitate calcium carbonate. They found that the strength of the specimen using the plant extract was increased to about $300 \mathrm{kPa}$, approximately 3 times higher than that of the untreated specimen. However, the process of getting the primary and the secondary liquid from the plant extract is not simple, and maximum $5 \%$ of cement is obtained after 4 days. Therefore, it takes several days to have the maximum amount of cement even after mixing the extract with the reaction solution.

In other countries, some researchers including Paassen et al. [7] (2008) and DeJong et al. [5, 6] have studied microbial cementation. DeJong et al. [5] achieved a desired strength through triaxial compression strength by continuous injection, but the process is very complicated. Whiffin et al. [8] obtained a great value of $10 \mathrm{MPa}$ for the specimen strength but estimated the strength with presumed values, not through quantitative analysis. Paassen et al. (2008) carried out a test in a model soil tank. The test results revealed that the strength increased along the surface and the part where air is available enough, but slight strength increase was observed in the central part which did not have enough air.

Paassen et al. [7] (2008), DeJong et al. [5, 6], Whiffin et al. [8], and Park et al. [2] used an aqueous solution of calcium carbonate to enhance the strength of soft ground. However, calculation of strength by means of estimates is not highly reliable, and the aqueous solution of calcium carbonate lowers strength, and it is not easy to handle the supernatant liquid if much of the solution is injected. The calcium carbonate used in this study is produced through the reaction between a microbial solution and an aqueous solution of calcium chloride. It is produced as powder like cement which is widely used as a construction material, and it is possible to identify the effect of increased quantitative strength, unlike prior studies.

\section{Method of Producing Specimens}

\subsection{Materials Used in the Test}

2.1.1. Sand and Cement. The sample sand was collected from the riverside of the Seomjingang River, Sangdong-myon, Namwon, Jeollabuk-do. Sieve analysis was performed for the collected sample to use the sample mixed in the ratio of $1: 1: 1$ with the sample remaining in the sieves $\# 60(0.25 \mathrm{~mm})$,

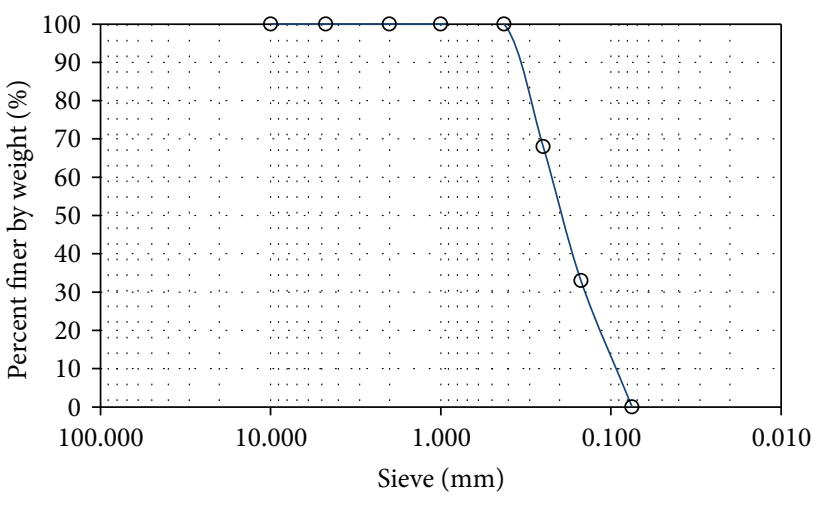

Figure 1: Particle size of the sample test results.

$\# 100(0.15 \mathrm{~mm})$, and \#200 $(0.075 \mathrm{~mm})$ in order to produce self-standing specimens to measure strength through the uniaxial compression test. Figure 1 shows the result of soil analysis for the sand sample used in this study. Here, the result of calculation of the coefficient of uniformity and the curvature with the particle-size distribution curve is 2.63 for the coefficient of uniformity $\left(C_{u}\right)$ and 0.94 for the coefficient of curvature $\left(C_{g}\right)$, which means SP sample of nonuniform particle size. The cement was Portland cement from a Korean company.

2.1.2. Calcium Carbonate Produced through Microbial Reaction. B. pasteurii (KCTC 3558) used in this study was purchased for bacterial culture from the Korean Collection for Type Culture of Korea Research Institute of Bioscience and Biotechnology. The culture medium for culturing $B$. pasteurii was Nutrient Broth $8 \mathrm{~g} / \mathrm{L}$, Urea $20 \mathrm{~g} / \mathrm{L}$. It was mixed with 1 liter of distilled water, and B. pasteurii was cultured in a shaking incubator of $180 \mathrm{RPM}$ at $30^{\circ} \mathrm{C}$. Equation (1) is for the reaction between microbes and urea. Growing microbes react with urea to be hydrolyzed into a carbonate ion $\left(\mathrm{CO}_{3}{ }^{2-}\right)$ and two ammonium ions $\left(\mathrm{NH}_{4}^{+}\right)$:

$$
\mathrm{CO}\left(\mathrm{NH}_{2}\right)_{2}+2 \mathrm{H}_{2} \mathrm{O} \stackrel{\text { Urease reaction }}{\longrightarrow} \mathrm{CO}_{3}{ }^{2-}+2 \mathrm{NH}_{4}{ }^{+} \text {. }
$$

Calcium carbonate $\left(\mathrm{CaCO}_{3}\right)$ is produced by the reaction between carbonate ions $\left(\mathrm{CO}_{3}{ }^{2-}\right)$ produced through which B. pasteurii takes urea and the calcium ions $\left(\mathrm{Ca}^{2+}\right)$ in the aqueous solution of calcium chloride $\left(\mathrm{CaCl}_{2}\right)$. Equation (2) is for the precipitation reaction of calcium carbonate:

$$
\mathrm{CO}_{3}{ }^{2-}+\mathrm{Ca}^{2+} \longrightarrow \mathrm{CaCO}_{3} .
$$

The calcium carbonate $\left(\mathrm{CaCO}_{3}\right)$ is produced through microbial reaction in the process described above. Figure 2 shows the process of producing calcium carbonate and the cycle of precipitating soil particles in each equation.

2.1.3. Powdering Calcium Carbonate. The calcium carbonate used in this study was produced through microbial reaction and then powdered like cement, unlike prior studies for which an aqueous solution of calcium carbonate was used. 


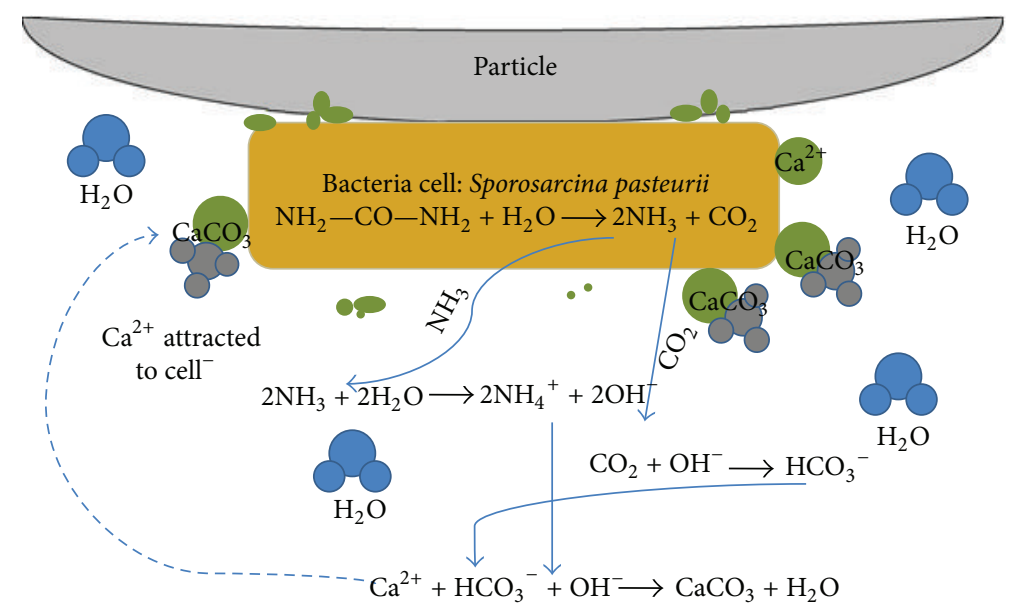

Net urea hydrolysis reaction: $\mathrm{NH}_{2}-\mathrm{CO}-\mathrm{NH}_{2}+3 \mathrm{H}_{2} \mathrm{O} \longrightarrow 2 \mathrm{NH}_{4}^{+}+\mathrm{HCO}_{3}{ }^{-}+\mathrm{OH}^{-}$

Net $\mathrm{pH}$ increase: $\left[\mathrm{OH}^{-}\right]$generated from $\mathrm{NH}_{4}{ }^{+}$production $\gg\left[\mathrm{Ca}^{2+}\right]$

Figure 2: Process of producing calcium carbonate [6].

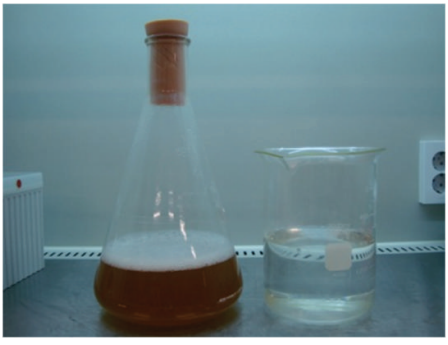

(a)

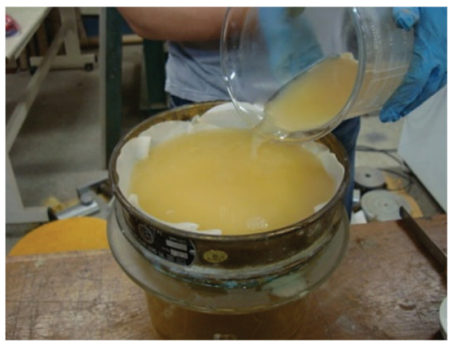

(d)

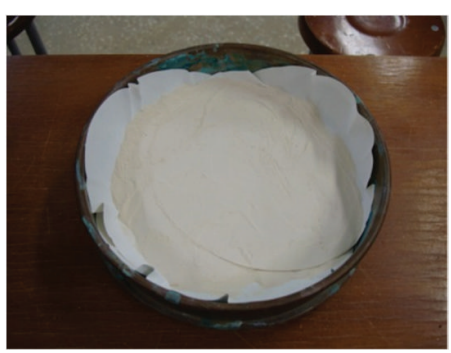

(g)

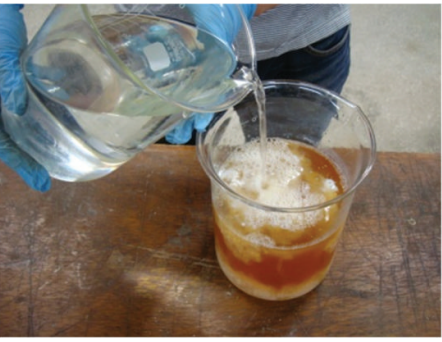

(b)

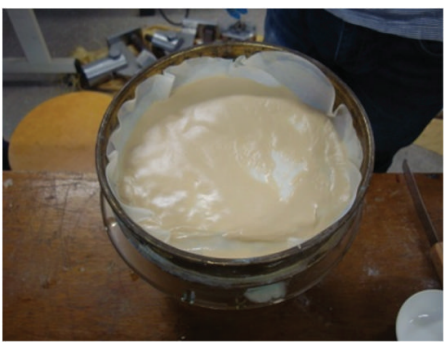

(e)

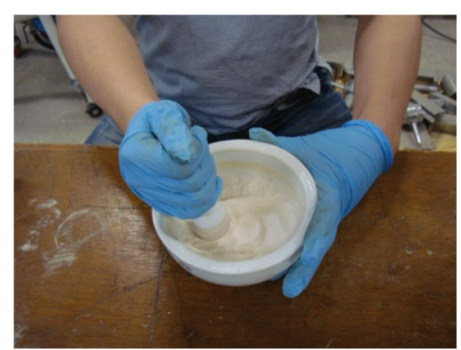

(h)

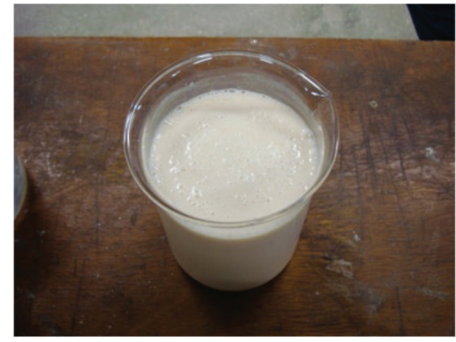

(c)

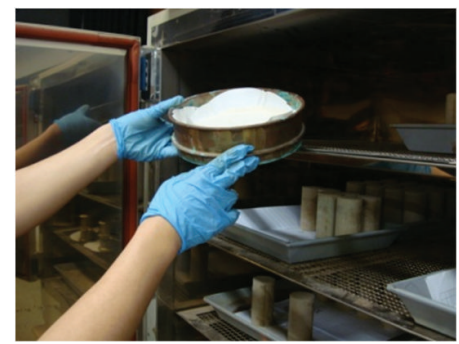

(f)

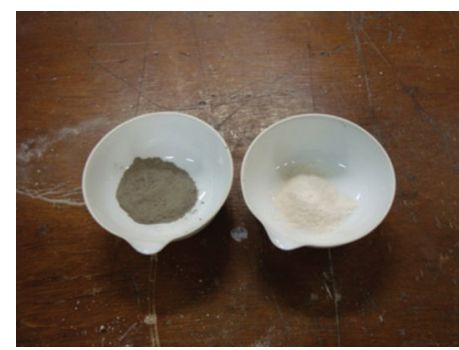

(i)

FIgURE 3: Extracting and producing calcium carbonate. 
The microbial reaction was done by adding calcium chloride into bacteria solution. The powdered calcium carbonate enabled the supernatant liquid to be handled and quantitative strength to be measured, which was an issue in prior studies. Figure 3 shows the process of extracting, drying, and powdering calcium carbonate from the microbial solution and the aqueous solution of calcium chloride. In the method described below, the calcium carbonate produced through microbial reaction was used as a cementation agent.

Figure 3 shows (a) a medium for microbes (1L); (b) mixing the aqueous solution of calcium chloride (1L); (c) precipitating calcium carbonate in the reaction solution; (d) filtering the reaction solution; (e) extracting calcium carbonate; (f) drying calcium carbonate at $40^{\circ} \mathrm{C}$ for 24 hours; (h) powdering calcium carbonate.

2.2. Producing Specimens. Specimens of which the ratio of height to the diameter were produced to be $1: 2$ in the ratio of the diameter (D) $5 \mathrm{~cm}$ to the height $(\mathrm{H}) 10 \mathrm{~cm}$ as shown in Figure 4 in conformity with the Korea Industrial Standard KS F2314. This aimed to measure the uniaxial compression strength of the specimens of calcium carbonate (produced through microbial reaction), cement, and calcium carbonate + cement. The process applied was (a) to measure the weight of the sample material, the cement, and the water, respectively, (b) to hand-mix the sample material, (c) to produce specimens in a mold through 3-layer compaction, (d) to cure the specimens at $40^{\circ} \mathrm{C}$, (e) to remove the cured specimen mold, and (f) to measure the uniaxial compression strength of the specimens.

The 65 produced specimens were divided into 4 cases of 5 untreated specimens, 20 calcium carbonate specimens, 20 cement specimens, and 20 calcium carbonate + cement specimens. The untreated specimens were produced to correspond to 3 days, 7 days, 14 days, 21 days, and 28 days. Five specimens for each of calcium carbonate, cement, and calcium carbonate + cement were produced to have the weight ratios of $2 \%$, $4 \%, 6 \%$, and $8 \%$ to measure the strength depending on the curing period ( 3 days, 7 days, 14 days, 21 days, and 28 days). Table 1 shows the mixing ratio of the specimens untreated, calcium carbonate, cement, and calcium carbonate + cement, with which 5 specimens were produced, respectively.

\section{Analysis of Test Results}

3.1. Uniaxial Compression Test Result of Untreated Specimens. The uniaxial compression strength test was carried out for the specimens at a shearing speed of $1 \% / \mathrm{min}$. Table 2 and Figure 5 show the results of uniaxial compression strength test for the untreated specimens after curing them for 3 days, 7 days, 14 days, 21 days, and 28 days.

The untreated sand specimens to which the cementation agent was not added stood for themselves as a circular cylinder by means of apparent cohesion, and the uniaxial compression strength thereof was $53.42 \mathrm{kPa}$ for the initial curing ( 3 days), which is shown in Table 2. For curing for 28 days, the result was $64.10 \mathrm{kPa}$, which increased approximately
1.2 times. This increase is due to the drying moisture in the specimens.

3.2. Results of Uniaxial Compression Test for Calcium Carbonate Specimens. The calcium carbonate specimens were tested at the shearing speed of $1 \% / \mathrm{min}$ in the same method as the uniaxial compression strength test for untreated specimens. The result of the uniaxial compression test for the calcium carbonate specimens after curing them for 3 days, 7 days, 14 days, 21 days, and 28 days is shown in Table 3 and Figure 6. As shown in Table 3, the initial strength (3 days) of the calcium carbonate specimens was $84.57-199.95 \mathrm{kPa}$, which exhibits increased strength approximately 2.4 times with the increased weight ratio. It is thought that the increased amount of calcium carbonate affects the increased strength of the sand ground. The strength increased approximately 2.6-2.7 times with the increased weight ratio for the curing period of 7 days, 14 days, 21 days, and 28 days. The calcium carbonate specimens also exhibited increased strength with the longer curing period like the untreated specimens.

As shown in Figure 7, it is thought that the uniaxial compression strength of the calcium carbonate specimens increased with the longer curing period. While the calcium carbonate powder was mixed with water and then dried around the sand particles in producing the specimens, evaporating water contributed to shrinking for holding sand particles. The strength of the calcium carbonate specimens increased approximately minimum 1.6 times for the curing period of 3 days in comparison with the untreated specimens.

3.3. Results of Uniaxial Compression Test of Cement Specimens. The uniaxial compression test was carried out for the cement specimens in the same method as the one for the untreated and the calcium carbonate specimens described above. Table 4 and Figure 8 show the result of the uniaxial compression strength test for the cement specimens after curing them for the period of 3 days, 7 days, 14 days, 21 days, and 28 days. The initial strength (3 days) of the cement specimens was $128.45-876.06 \mathrm{kPa}$, which increased approximately 6.8 times with the increased ratio, even higher than the strength of the untreated and the calcium carbonate specimens previously tested. This proves the effect of enhanced strength of ordinary cement specimens.

It was seen that the cement specimens also exhibited increased strength approximately 7.0-8.0 times with the increased weight ratio for the curing period of 7 days, 14 days, 21 days, and 28 days. It is thought that the reaction of hydration and the Pozzolanic reaction of cement contributed to the effect of even enhanced strength with longer curing period than the enhanced strength of the untreated and the calcium carbonate specimens previously tested. The effect of enhanced strength is shown in Figure 9. The strength of the cement specimens increased approximately 16.4-18.8 times in comparison with the untreated specimens.

3.4. Results of Uniaxial Compression Test of Calcium Carbonate + Cement Specimens. The uniaxial compression strength of the calcium carbonate + cement specimens was tested at a 


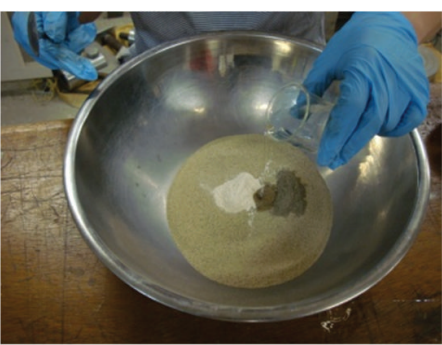

(a)

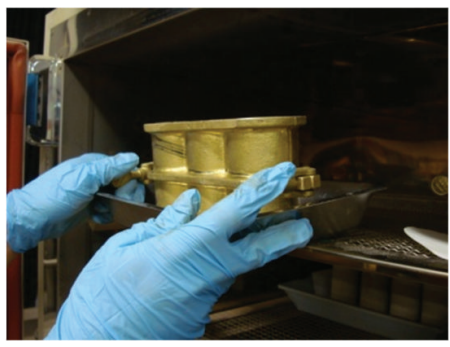

(d)

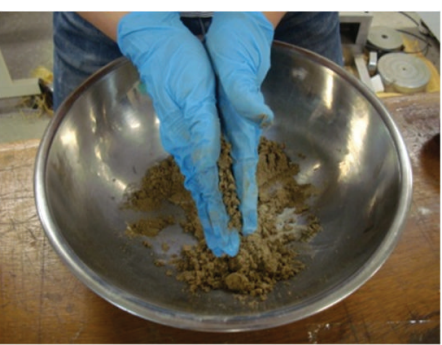

(b)

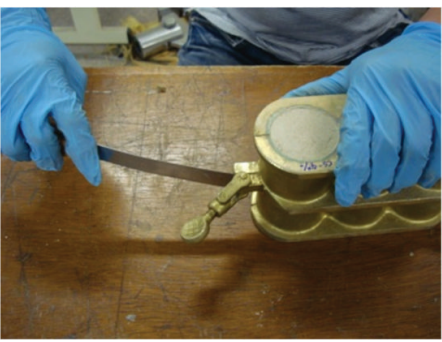

(e)

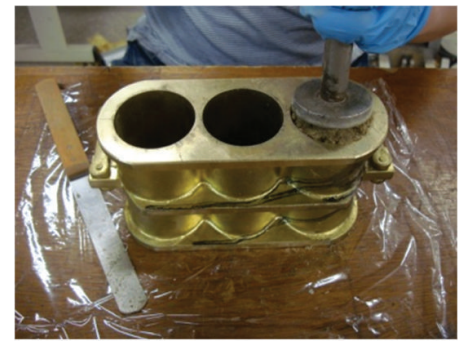

(c)

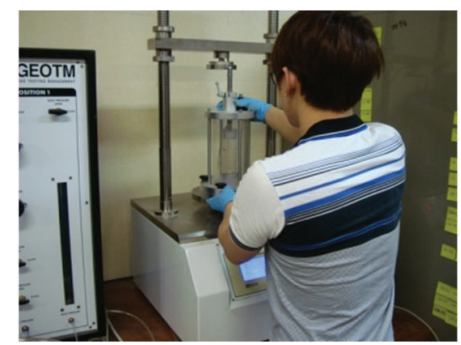

(f)

Figure 4: Mixing sample materials and producing specimens.

TABLE 1: Mixing the sample material.

\begin{tabular}{|c|c|c|c|c|c|c|c|}
\hline Test ID & Cementation material & Soil (g) & Water (g) & Weight ratio (\%) & Calcium carbonate $(\mathrm{g})$ & Cement (g) & Quantity \\
\hline Untreated & - & 275 & 50 & - & - & - & 5 \\
\hline $\mathrm{C}-2 \%$ & \multirow{4}{*}{ Calcium carbonate } & 275 & 50 & 2 & 5.5 & - & 5 \\
\hline C- $4 \%$ & & 275 & 50 & 4 & 11 & - & 5 \\
\hline C-6\% & & 275 & 50 & 6 & 16.5 & - & 5 \\
\hline $\mathrm{C}-8 \%$ & & 275 & 50 & 8 & 22 & - & 5 \\
\hline S-2\% & \multirow{4}{*}{ Cement } & 275 & 50 & 2 & - & 5.5 & 5 \\
\hline S- $4 \%$ & & 275 & 50 & 4 & - & 11 & 5 \\
\hline S-6\% & & 275 & 50 & 6 & - & 16.5 & 5 \\
\hline S-8\% & & 275 & 50 & 8 & - & 22 & 5 \\
\hline CS-2\% & \multirow{4}{*}{ Calcium carbonate + cement } & 275 & 50 & 2 & 2.25 & 2.25 & 5 \\
\hline CS- $4 \%$ & & 275 & 50 & 4 & 5.5 & 5.5 & 5 \\
\hline CS-6\% & & 275 & 50 & 6 & 11 & 11 & 5 \\
\hline CS- $8 \%$ & & 275 & 50 & 8 & 16.5 & 16.5 & 5 \\
\hline
\end{tabular}

TABLE 2: Curing period to compare strength of untreated specimens (unit: $\mathrm{kPa}$ ).

\begin{tabular}{lccccc}
\hline \multirow{2}{*}{ Specimen } & \multicolumn{4}{c}{ Curing period to compare strength of untreated specimens } \\
& 3 days & 7 days & 14 days & 21 days & 28 days \\
\hline Untreated & 53.42 & 54.42 & 59.17 & 60.32 & 64.1 \\
\hline
\end{tabular}

TABLE 3: Curing period to compare the strength of calcium carbonate specimens (unit: $\mathrm{kPa}$ ).

\begin{tabular}{|c|c|c|c|c|c|}
\hline \multirow{2}{*}{ Test ID } & \multicolumn{5}{|c|}{ Curing period to compare the strength of calcium carbonate specimens } \\
\hline & 3 days & 7 days & 14 days & 21 days & 28 days \\
\hline Untreated & 53.42 & 54.42 & 59.17 & 60.32 & 64.10 \\
\hline C- $2 \%$ & 84.57 & 92.44 & 98.35 & 103.34 & 139.88 \\
\hline $\mathrm{C}-4 \%$ & 120.69 & 142.10 & 159.60 & 168.16 & 205.78 \\
\hline $\mathrm{C}-6 \%$ & 152.48 & 158.88 & 173.12 & 237.24 & 249.08 \\
\hline C- $8 \%$ & 199.95 & 251.43 & 254.20 & 281.71 & 378.86 \\
\hline
\end{tabular}


TABLE 4: Curing period to compare the strength of cement specimens (unit: $\mathrm{kPa}$ ).

\begin{tabular}{|c|c|c|c|c|c|}
\hline \multirow{2}{*}{ Test ID } & \multicolumn{5}{|c|}{ Curing period to compare the strength of cement specimens } \\
\hline & 3 days & 7 days & 14 days & 21 days & 28 days \\
\hline Untreated & 53.42 & 55.42 & 59.17 & 60.32 & 64.10 \\
\hline S-2\% & 128.45 & 134.17 & 137.58 & 161.41 & 170.99 \\
\hline S- $4 \%$ & 268.47 & 330.15 & 342.26 & 456.78 & 459.06 \\
\hline S-6\% & 618.13 & 641.79 & 666.99 & 695.76 & 738.54 \\
\hline $\mathrm{S}-8 \%$ & 876.06 & 1050.73 & 1111.4 & 1184.69 & 1206.69 \\
\hline
\end{tabular}

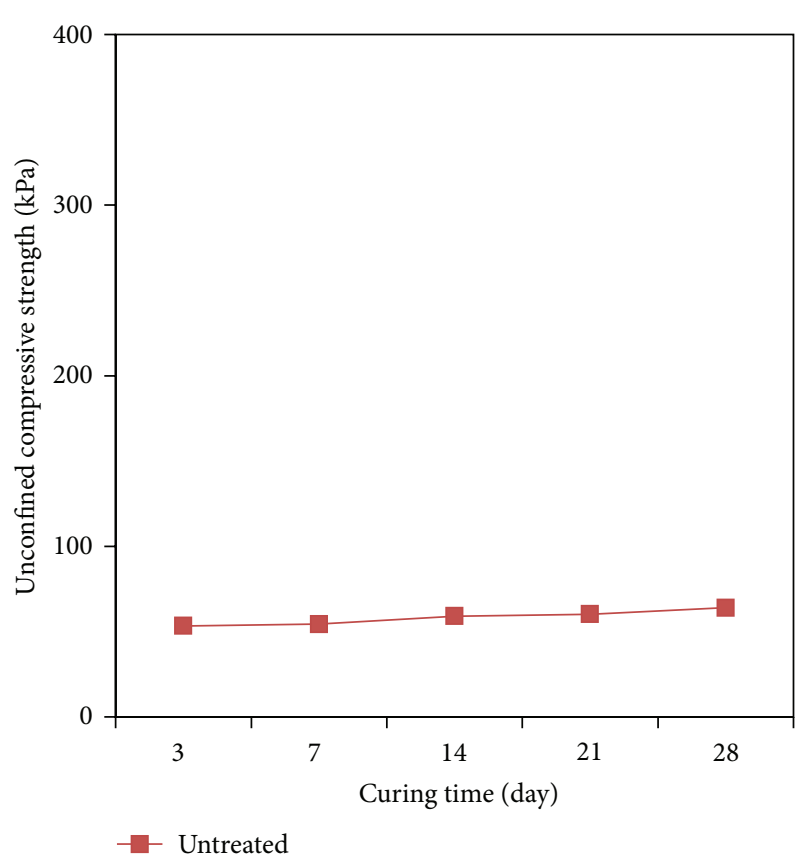

FIGURE 5: Curing period to compare strength of untreated specimens.

shearing speed of $1 \% / \mathrm{min}$ in the same method as the one for the previous specimens. The uniaxial compression strength test of the calcium carbonate + cement specimens was carried out by mixing calcium carbonate with cement to determine compatibility as an admixture. Table 5 and Figure 10 show the result of uniaxial compression test for the calcium carbonate + cement specimens after curing them for 3 days, 7 days, 14 days, 21 days, and 28 days. The initial strength (3 days) of the calcium carbonate + cement specimens was 36.80$367.78 \mathrm{kPa}$, which increased approximately 10 times with the increased amount of calcium carbonate + cement in the specimens. This strength is higher than the initial strength of the previous specimens.

The specimens produced by curing calcium carbonate + cement with $2 \%$ of the weight ratio for 3 days exhibited 1.4 times lower uniaxial compression strength than the strength of the untreated specimens. This is quite different from what we expected. It is thought that this resulted from the fact that a small amount of calcium carbonate and cement was not

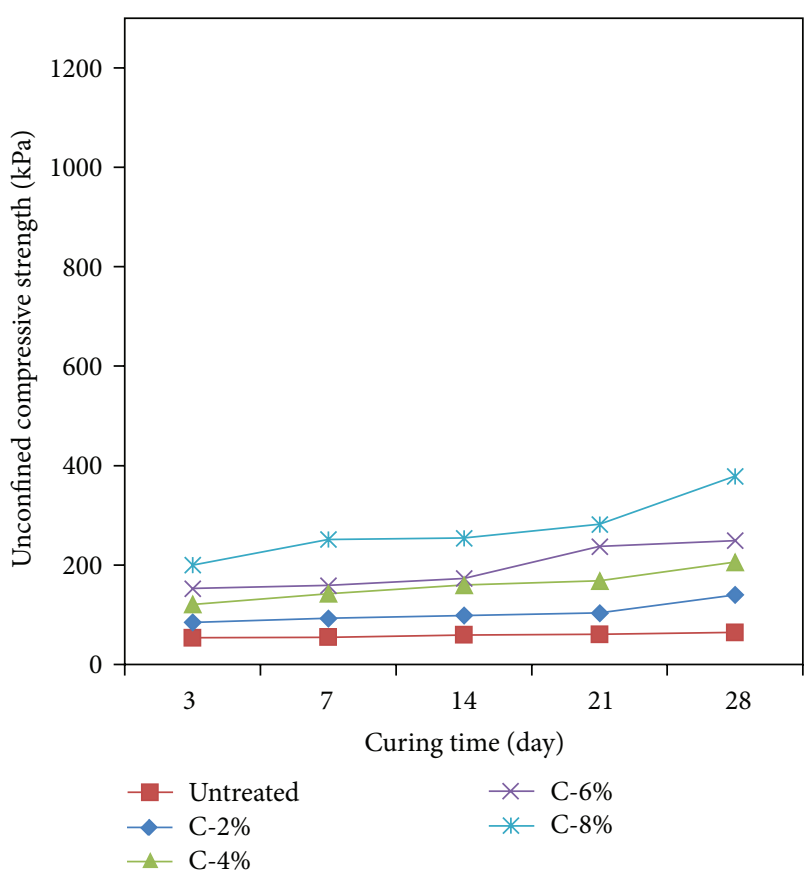

FIGURE 6: Curing period to compare the strength of calcium carbonate specimens.

fully dried to inhibit cohesion to result in lowered strength. However, the increased weight ratio contributed to increasing the strength approximately 6.7-8.6 times with respect to the curing periods of 7 days, 14 days, 21 days, and 28 days. It was identified that the strength that increased approximately $1.3-$ 3.0 times was attributable to longer curing period. The $2 \%$ and $4 \%$ calcium carbonate (low weight ratio) + cement specimens showed similar tendency to the increased strength of the untreated specimens with longer curing period. However, the $6 \%$ and $8 \%$ calcium carbonate (high weight ratio) + cement specimens showed higher strength than that of the cement specimens. The tendency showed that the calcium carbonate + cement specimens had a less effect of cement in the low weight ratio and in the early stage of curing but showed increased strength because of more cement contents in the specimens as the weight ratio increased. It is thought that this will contribute to a highly strong and environmentally safe admixture by studying the mixture of environment-friendly calcium carbonate produced through the reaction between cement and net microbes. 


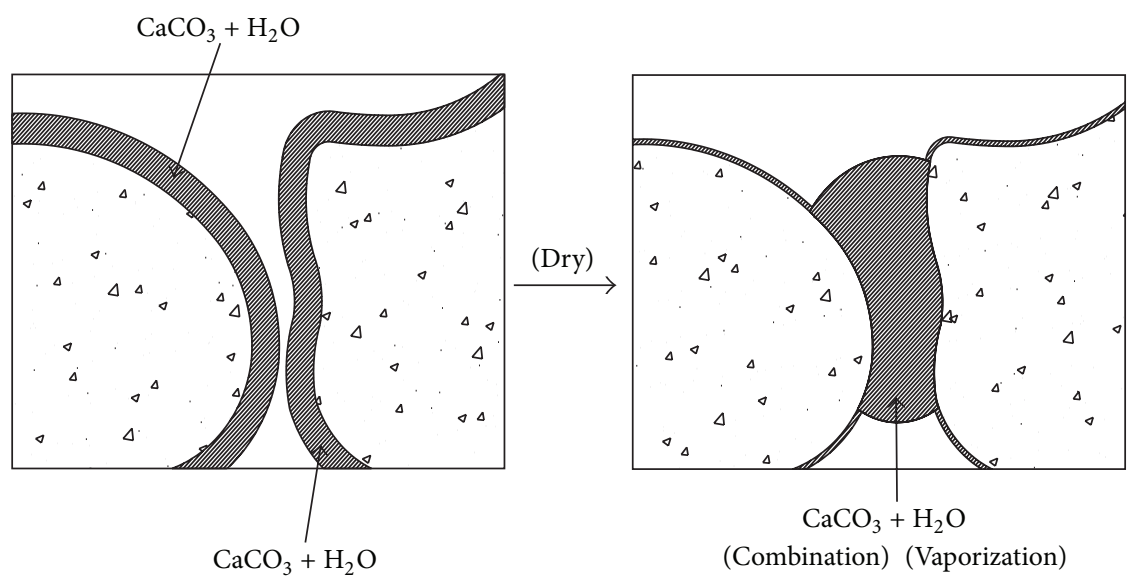

FIGURE 7: Effect of enhancing strength of calcium carbonate specimens.

TABLE 5: Curing period to compare the strength of calcium carbonate + cement specimens (unit: $\mathrm{kPa}$ ).

\begin{tabular}{|c|c|c|c|c|c|}
\hline \multirow{2}{*}{ Test ID } & \multicolumn{5}{|c|}{ Curing period to compare the strength of calcium carbonate + cement specimens } \\
\hline & 3 days & 7 days & 14 days & 21 days & 28 days \\
\hline Untreated & 53.42 & 55.42 & 59.17 & 60.32 & 64.10 \\
\hline CS-2\% & 36.80 & 61.12 & 62.79 & 67.83 & 76.45 \\
\hline CS- $4 \%$ & 56.93 & 94.78 & 118.81 & 140.19 & 169.56 \\
\hline CS-6\% & 275.26 & 333.96 & 335.70 & 338.75 & 352.78 \\
\hline CS- $8 \%$ & 367.78 & 407.14 & 436.60 & 499.94 & 654.27 \\
\hline
\end{tabular}

3.5. Results of Uniaxial Compression Test. The uniaxial compression strength of the calcium carbonate, cement, and calcium carbonate + cement specimens analyzed above was compared with respect to the different weight ratios $(2 \%, 4 \%$, $6 \%$, and $8 \%$ ). This was intended to compare and analyze the change of the uniaxial compression strength of calcium carbonate, cement, and calcium carbonate + cement specimens with respect to the same weight ratios. Figure 8 shows analysis and comparison for the effect of enhanced strength in the weak sandy soil ground by each cementation agent.

Figures 11(a)-11(d) show the result of each specimen corresponding to (a) weight ratio $2 \%$, (b) weight ratio $4 \%$, (c) weight ratio $6 \%$, and $(\mathrm{d})$ weight ratio $8 \%$ for comparing the strength of each specimen depending on the weight ratio.

Figure 11(a) shows the result of weight ratio $2 \%$. For weight ratio $2 \%$, higher strength was measured in the order of untreated, calcium carbonate, cement, and calcium carbonate + cement specimens, but most specimens showed a similar tendency to the untreated specimens. It is thought that a small amount of the cementation agent does not significantly affect the enhancement of strength.

Figure 11(b) shows the result of weight ratio $4 \%$. For weight ratio $4 \%$, higher strength was measured in the order of untreated, calcium carbonate + cement, calcium carbonate, and cement specimens. The cement specimens showed 2.2-2.7 times higher strength than the calcium carbonate specimens. The calcium carbonate specimens showed 1.12.1 times higher strength than the calcium carbonate + cement specimens, but a similar tendency was shown. It is thought that because the cement contents of the calcium carbonate + cement specimens are smaller than those of the cement specimens, the calcium carbonate + cement specimens showed lower uniaxial compression strength than that of the calcium carbonate specimens.

Figure 11(c) shows the result of weight ratio 6\%. For weight ratio $6 \%$, higher strength of the specimens was measured in the order of untreated, calcium carbonate, calcium carbonate + cement, and cement specimens, unlike the uniaxial compression strength of the $2 \%$ and $4 \%$ specimens. The cement specimens showed 3.8-4.0 times higher uniaxial compression strength than that of the calcium carbonate specimens. The calcium carbonate + cement specimens showed 1.4-2.0 times higher uniaxial compression strength than that of the calcium carbonate specimens.

Figure $11(\mathrm{~d})$ shows the result of weight ratio $8 \%$. For weight ratio $8 \%$, higher strength of the specimens was measured in the order of weight ratio $6 \%$. The cement specimens showed 3.2-4.4 times higher uniaxial compression strength than that of the calcium carbonate specimens. The calcium carbonate + cement specimens showed 1.6-1.8 times higher uniaxial compression strength than that of the calcium carbonate specimens. The uniaxial compression strength of the highest weight ratio $8 \%$ specimens gradually increased as the amount of the cementation agent increased with the sand weight in a given specimen.

The analysis of the graph for the calcium carbonate and calcium carbonate + cement specimens reveals that the increase of the uniaxial compression strength with the 


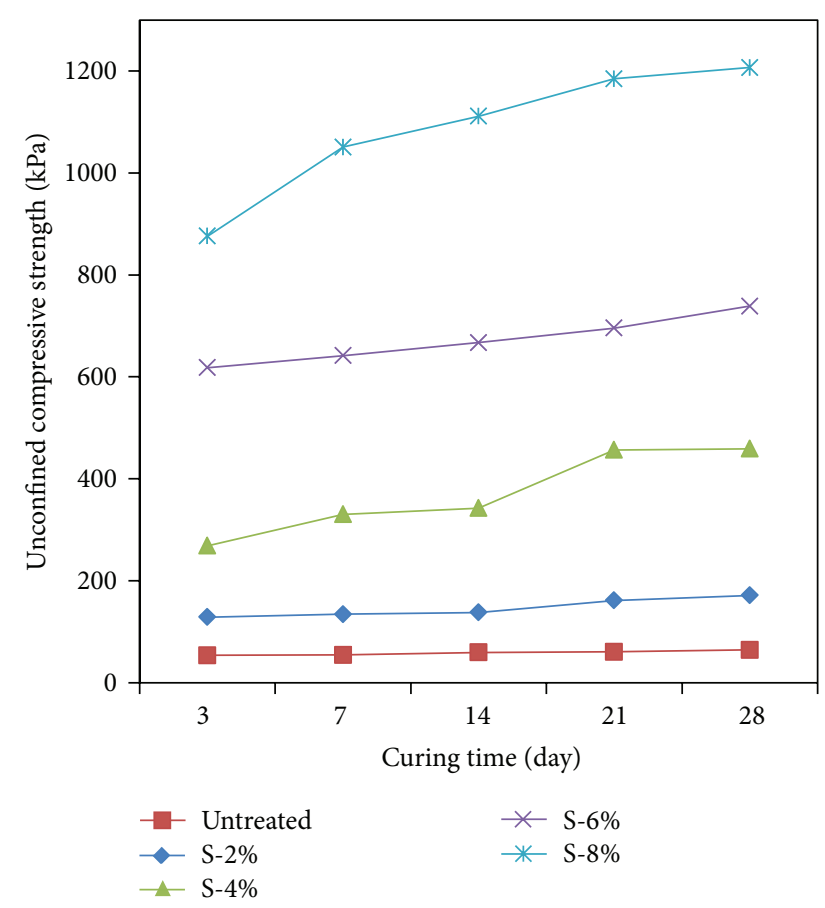

FIGURE 8: Curing period to compare the strength of cement specimens.

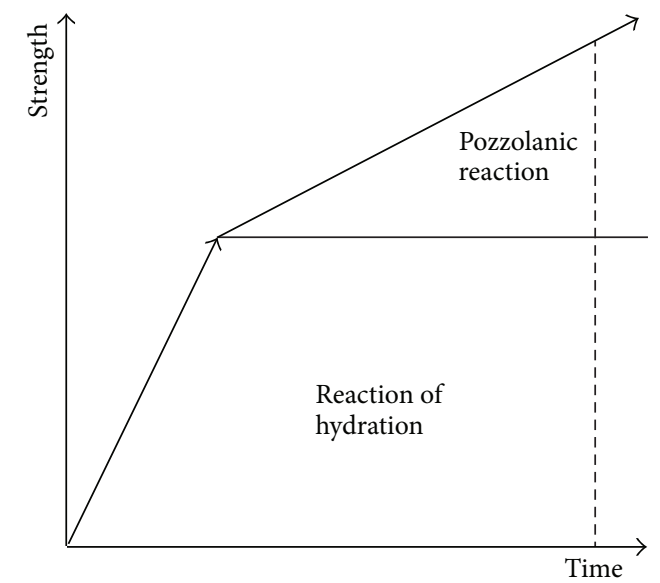

FIGURE 9: Enhanced strength through ground improvement with cement.

increased weight ratio is not significant like the cement specimens. However, because longer period for curing the calcium carbonate and calcium carbonate + cement specimens tends to contribute to enhanced strength, it is thought that the effect of enhancing strength in the weak sand ground will be implemented.

3.6. Results of X-Ray Diffraction Analysis (XRD). XRD analysis was carried out to identify ores created in the calcium carbonate produced by means of microbes, cement, and calcium carbonate + cement specimens. Each sample was reduced to fine powder, and the diffraction angle of X-rays was set as

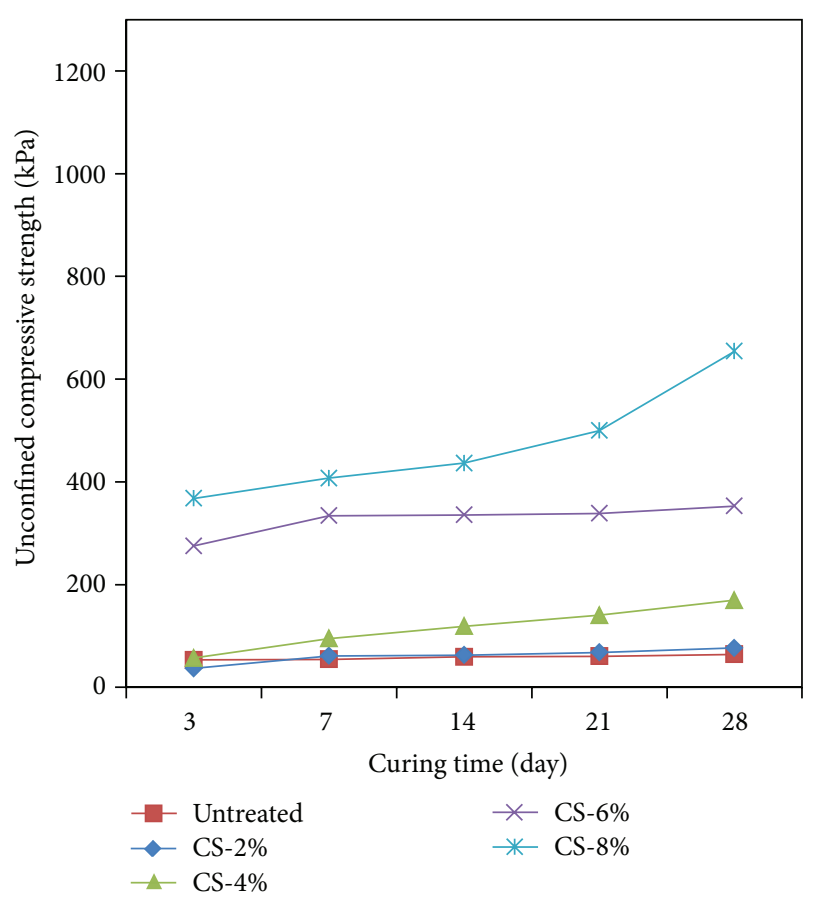

FIGURE 10: Curing period to compare the strength of calcium carbonate + cement specimens.

$5-70^{\circ}$ for 2 . For the calcium carbonate specimens, the result of identified silica $\left(\mathrm{SiO}_{2}\right)$ and calcium carbonate $\left(\mathrm{CaCO}_{3}\right)$ was described to compare the result of identification in the cement specimens. Silica $\left(\mathrm{SiO}_{2}\right)$ which is a representative ore of cement and aluminum oxide $\left(\mathrm{Al}_{2} \mathrm{O}_{3}\right)$ was identified in the cement specimens. The result of identification in the calcium carbonate + cement specimens includes silica $\left(\mathrm{SiO}_{2}\right)$, aluminum oxide $\left(\mathrm{Al}_{2} \mathrm{O}_{3}\right)$, and calcium carbonate $\left(\mathrm{CaCO}_{3}\right)$. Table 5 shows the result of XRD analysis for each specimen, which includes right minerals in each specimen. Note that the percentage of calcium carbonate is larger in the specimen with calcium carbonate than the specimen with calcium carbonate+cement.

\section{Summary and Conclusions}

This study aims to identify the effect of enhanced strength by calcium carbonate produced through microbial reaction in the sandy soil ground by means of the uniaxial compression test.

Specimens with weight ratios $2 \%, 4 \%, 6 \%$, and $8 \%$ were produced to measure the uniaxial compression strength for the curing periods of 3 days, 7 days, 14 days, 21 days, and 28 days and to identify the type of minerals contained in the specimens by means of XRD analysis (Table 6).

(1) The uniaxial compression strength was measured to be $84.57-378.86 \mathrm{kPa}$ after curing the calcium carbonate specimens for each weight ratio for 3 days, 7 days, 14 days, 21 days, and 28 days. It was identified that the strength of calcium carbonate produced by means of microbial reaction increased approximately 


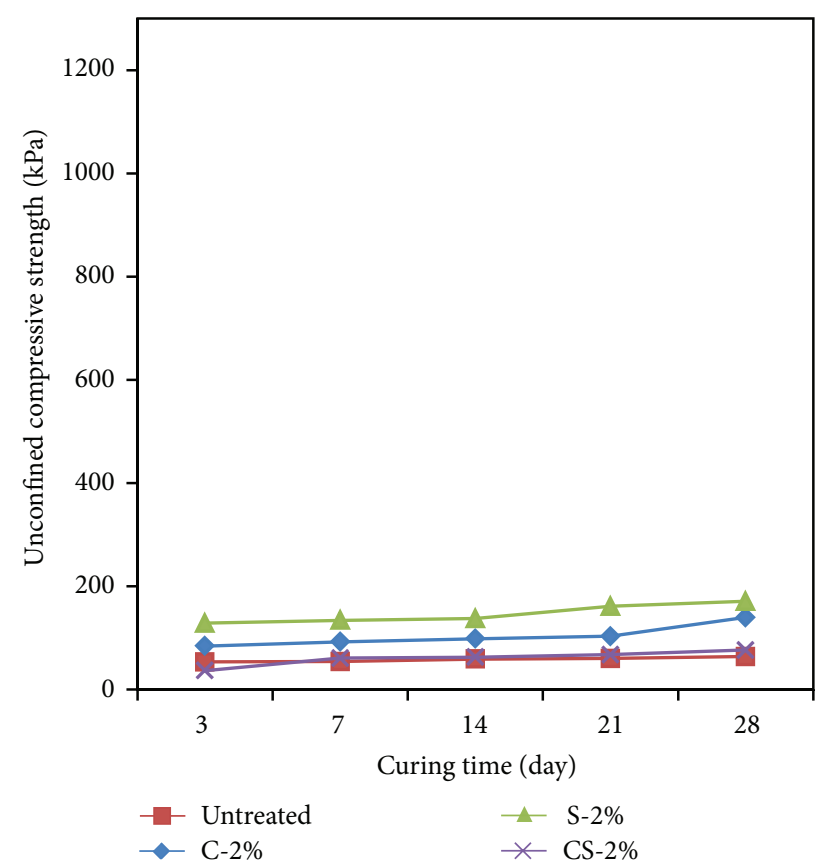

(a)

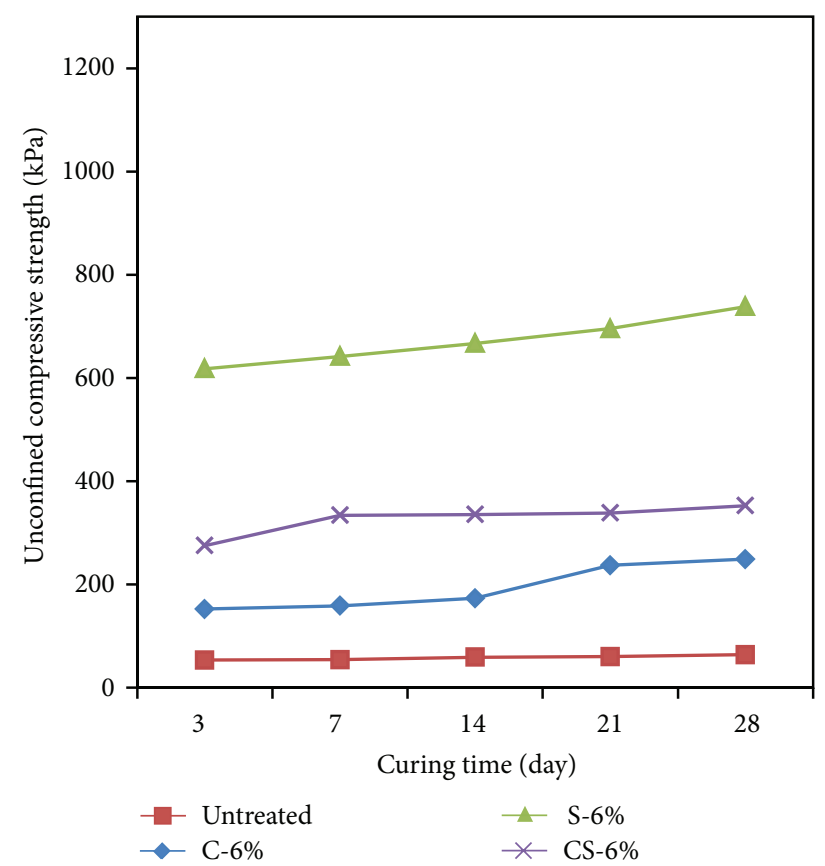

(c)

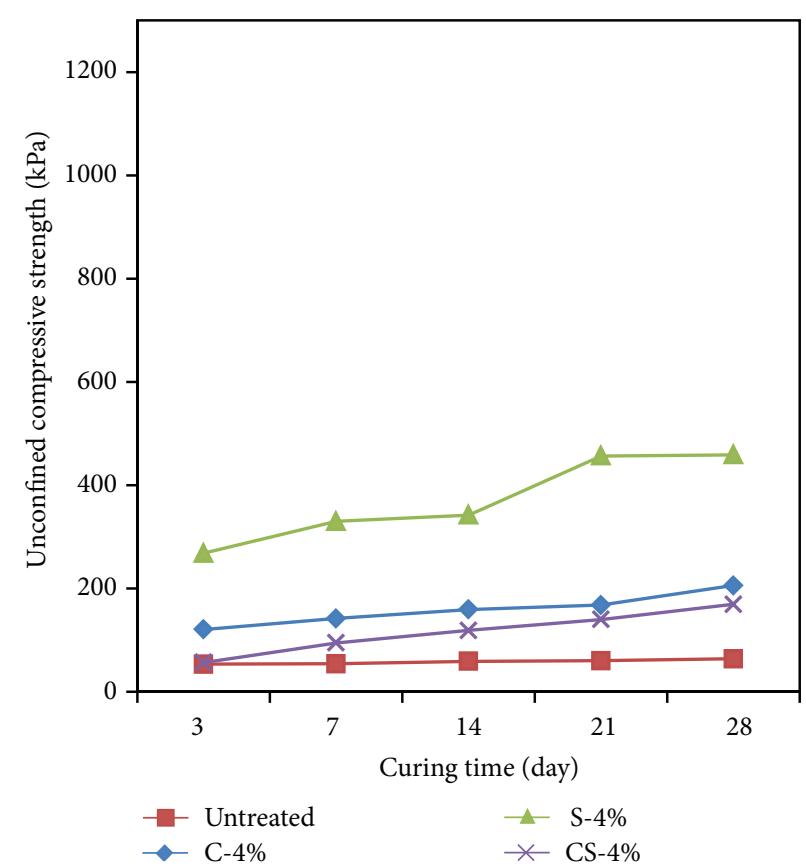

(b)

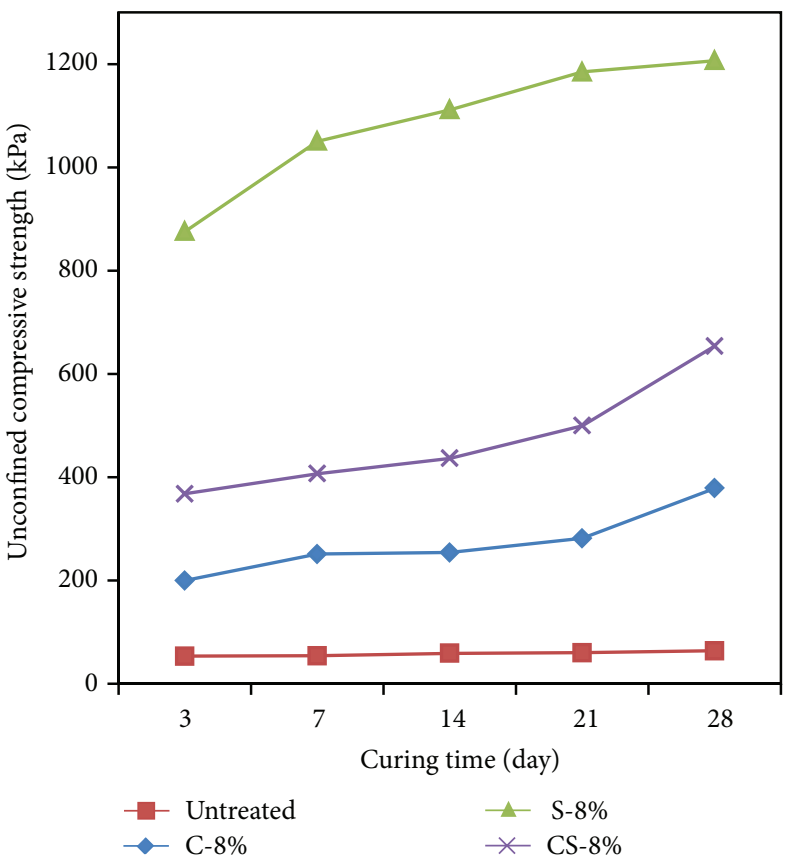

(d)

FIGURE 11: Strength of specimens by weight ratios.

1.5 times with the increased period of curing in comparison with initial curing. As the amount of calcium carbonate in specimens increased, their strength also increased. It is thought that shrinking for sand particles holding together due to water evaporation in the specimens contributed to increased uniaxial compression strength with the longer period of curing.

(2) The strength of cement specimens was measured to be $128.45-1,206.69 \mathrm{kPa}$ for each weight ratio after curing them for 3 days, 7 days, 14 days, 21 days, and 28 days. The analysis revealed that the reaction of hydration and the increased strength of the sandy soil were attributable to the reaction of hydration and Pozzolanic reaction as the amount of cement and the period of curing increased.

(3) The uniaxial compression strength of calcium carbonate + cement specimens was measured to be $128.45-$ $654.27 \mathrm{kPa}$ for each weight ratio after curing them 
TABLE 6: Specimen curing period in accordance with the results of XRD analysis.

\begin{tabular}{|c|c|c|c|}
\hline Test ID & Formula & Scale factor & Score \\
\hline \multirow{2}{*}{ C3-4\% } & $\mathrm{SiO}_{2}$ & 0.308 & 54 \\
\hline & $\mathrm{CaCO}_{3}$ & 0.124 & 12 \\
\hline \multirow{2}{*}{ C7-4\% } & $\mathrm{SiO}_{2}$ & 0.326 & 63 \\
\hline & $\mathrm{CaCO}_{3}$ & 0.286 & 34 \\
\hline \multirow{2}{*}{ C14-4\% } & $\mathrm{SiO}_{2}$ & 0.352 & 70 \\
\hline & $\mathrm{CaCO}_{3}$ & 0.354 & 12 \\
\hline \multirow{2}{*}{ C21-4\% } & $\mathrm{SiO}_{2}$ & 0.404 & 80 \\
\hline & $\mathrm{CaCO}_{3}$ & 0.450 & 10 \\
\hline \multirow{2}{*}{ C28-4\% } & $\mathrm{SiO}_{2}$ & 0.411 & 78 \\
\hline & $\mathrm{CaCO}_{3}$ & 0.556 & 12 \\
\hline \multirow{2}{*}{ S3-4\% } & $\mathrm{SiO}_{2}$ & 0.773 & 72 \\
\hline & $\mathrm{Al}_{2} \mathrm{O}_{3}$ & 0.097 & 22 \\
\hline \multirow{2}{*}{ S7-4\% } & $\mathrm{SiO}_{2}$ & 1.024 & 65 \\
\hline & $\mathrm{Al}_{2} \mathrm{O}_{3}$ & 0.271 & 21 \\
\hline \multirow{2}{*}{ S14-4\% } & $\mathrm{SiO}_{2}$ & 1.530 & 61 \\
\hline & $\mathrm{Al}_{2} \mathrm{O}_{3}$ & 0.278 & 11 \\
\hline \multirow{2}{*}{ S21-4\% } & $\mathrm{SiO}_{2}$ & 2.635 & 72 \\
\hline & $\mathrm{Al}_{2} \mathrm{O}_{3}$ & 0.301 & 17 \\
\hline \multirow{2}{*}{ S28-4\% } & $\mathrm{SiO}_{2}$ & 2.523 & 61 \\
\hline & $\mathrm{Al}_{2} \mathrm{O}_{3}$ & 0.329 & 7 \\
\hline \multirow{3}{*}{ CS3-4\% } & $\mathrm{SiO}_{2}$ & 0.962 & 73 \\
\hline & $\mathrm{Al}_{2} \mathrm{O}_{3}$ & 0.052 & 26 \\
\hline & $\mathrm{CaCO}_{3}$ & 0.152 & 11 \\
\hline \multirow{3}{*}{ CS7-4\% } & $\mathrm{SiO}_{2}$ & 0.995 & 79 \\
\hline & $\mathrm{Al}_{2} \mathrm{O}_{3}$ & 0.062 & 10 \\
\hline & $\mathrm{CaCO}_{3}$ & 0.152 & 16 \\
\hline \multirow{3}{*}{ CS14-4\% } & $\mathrm{SiO}_{2}$ & 0.999 & 67 \\
\hline & $\mathrm{Al}_{2} \mathrm{O}_{3}$ & 0.077 & 12 \\
\hline & $\mathrm{CaCO}_{3}$ & 0.162 & 10 \\
\hline \multirow{3}{*}{ CS21-4\% } & $\mathrm{SiO}_{2}$ & 1.010 & 50 \\
\hline & $\mathrm{Al}_{2} \mathrm{O}_{3}$ & 0.084 & 19 \\
\hline & $\mathrm{CaCO}_{3}$ & 0.172 & 8 \\
\hline \multirow{3}{*}{ CS28-4\% } & $\mathrm{SiO}_{2}$ & 1.100 & 72 \\
\hline & $\mathrm{Al}_{2} \mathrm{O}_{3}$ & 0.089 & 21 \\
\hline & $\mathrm{CaCO}_{3}$ & 0.175 & 11 \\
\hline
\end{tabular}

for 3 days, 7 days, 21 days, and 28 days. The mixture ratio of $1: 1$ of calcium carbonate produced by means of microbial reaction with cement resulted in less effect of cement in low weight ratio $2-4 \%$ specimens. However, it is thought that the enhanced strength of weight ratio $6 \sim 8 \%$ specimens is attributable to more cement contents in the specimens. It is expected that this will be an environment-friendly admixture to combine the environment-friendly calcium carbonate produced by means of net microbial reaction with cement.

It is thought that the strength of calcium carbonate, cement, and calcium carbonate + cement specimens increases for the sandy soil ground with the increased weight ratio and with longer period of curing them. For weight ratio $2 \%$, calcium carbonate achieved better effect in terms of strength than calcium carbonate + cement. However, for weight ratio $4-6 \%$, calcium carbonate + cement achieved more strength enhancement than calcium carbonate for the sandy soil ground. It is thought that this results from the fact that the increased weight ratio contributed to the increased amount of cement in the specimens to enhance strength by means of initial strength and the reaction of hydration. It is necessary to further study how to ideally mix calcium carbonate produced by means of microbes with cement to achieve higher strength of calcium carbonate + cement. Successful study will contribute to reducing the environmental costs for carbon dioxide emissions and excavation of lime.

\section{Conflict of Interests}

The authors declare that there is no conflict of interests regarding the publication of this paper.

\section{Acknowledgment}

This research was supported by Basic Science Research Program through the National Research Foundation of Korea (NRF) funded by the Ministry of Science, ICT and Future Planning (NRF-2013R1A1A105010106).

\section{References}

[1] D. H. Kim, H. C. Kim, and K. H. Park, "Cementation of soft soil using bacteria," Certificate of Patent, 10-1030761, 2012.

[2] S. S. Park, S. K. Choi, and I. H. Nam, "Development of ground cement using plant extract," Journal of Korean Geotechnical Society, vol. 28, no. 3, pp. 67-75, 2012.

[3] K. H. Park and D. H. Kim, "Identification of calcium carbonate for silt and sand treated with bacteria," Journal of Korean Geotechnical Society, vol. 28, no. 6, pp. 53-61, 2012.

[4] J. K. Mitchell and J. C. Santamarina, "Biological considerations in geotechnical engineering," Journal of Geotechnical and Geoenvironmental Engineering, vol. 131, no. 10, pp. 1222-1233, 2005.

[5] J. T. DeJong, M. B. Fritzges, and K. Nüsslein, "Microbially induced cementation to control sand response to undrained shear," Journal of Geotechnical and Geoenvironmental Engineering, vol. 132, no. 11, pp. 1381-1392, 2006.

[6] J. T. DeJong, B. M. Mortensen, B. C. Martinez, and D. C. Nelson, "Bio-mediated soil improvement," Ecological Engineering, vol. 36, no. 2, pp. 197-210, 2010.

[7] L. A. Paassen, M. P. Harkes, G. A. Zwieten, W. H. Zon, W. R. L. Star, and M. C. M. Loosdrecht, "Scale up of biogrout: a biological ground reinforcement method," in Proceedings of the 17th International Conference on Soil Mechanics and Geotechnical Engineering, pp. 2328-2333, 2009.

[8] V. S. Whiffin, L. A. van Paassen, and M. P. Harkes, "Microbial carbonate precipitation as a soil improvement technique," Geomicrobiology Journal, vol. 24, no. 5, pp. 417-423, 2007.

[9] K. H. Park, Strength improvement of soft soil using soft soil [M.S. thesis], Chosun University, Gwangju, Korea, 2011. 
[10] K. H. Park and D. H. Kim, "Effect of strength and injection for the sand treated bacteria," Journal of Korean Geotechnical Society, vol. 29, no. 2, pp. 65-73, 2013.

[11] D. H. Kim, K. H. Park, and Y. H. Lee, "Effects of microbial treatment on biogrout," Journal of Korean Geotechnical Environmental Society, vol. 13, no. 5, pp. 51-67, 2012.

[12] H. C. Kim, Characteristics of cementation of soil using bacteria [M.S. thesis], Chosun University, Gwangju, Korea, 2011. 

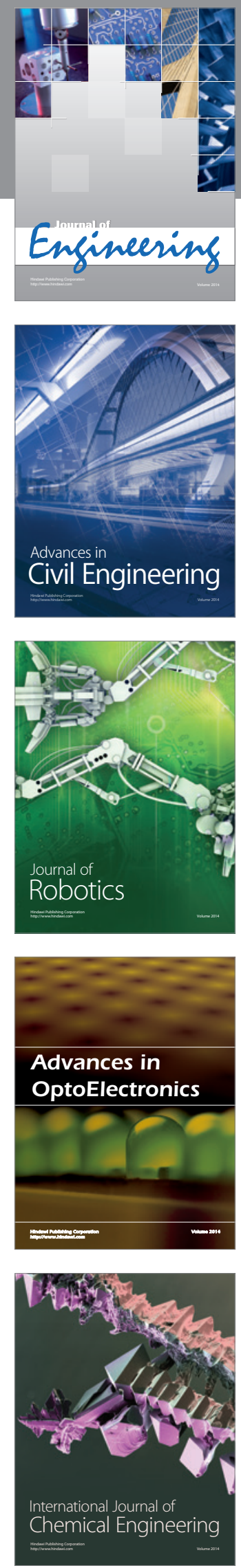

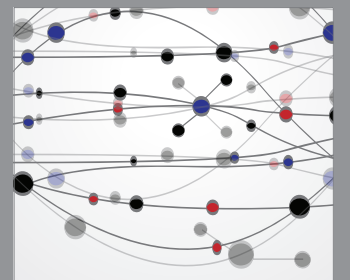

The Scientific World Journal
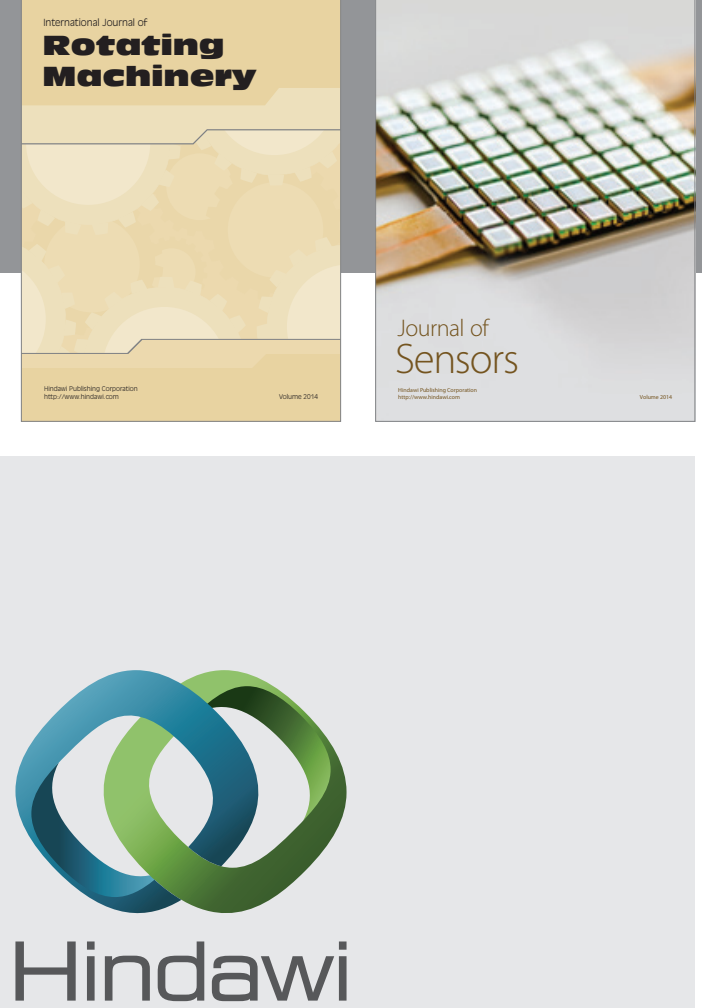

Submit your manuscripts at http://www.hindawi.com
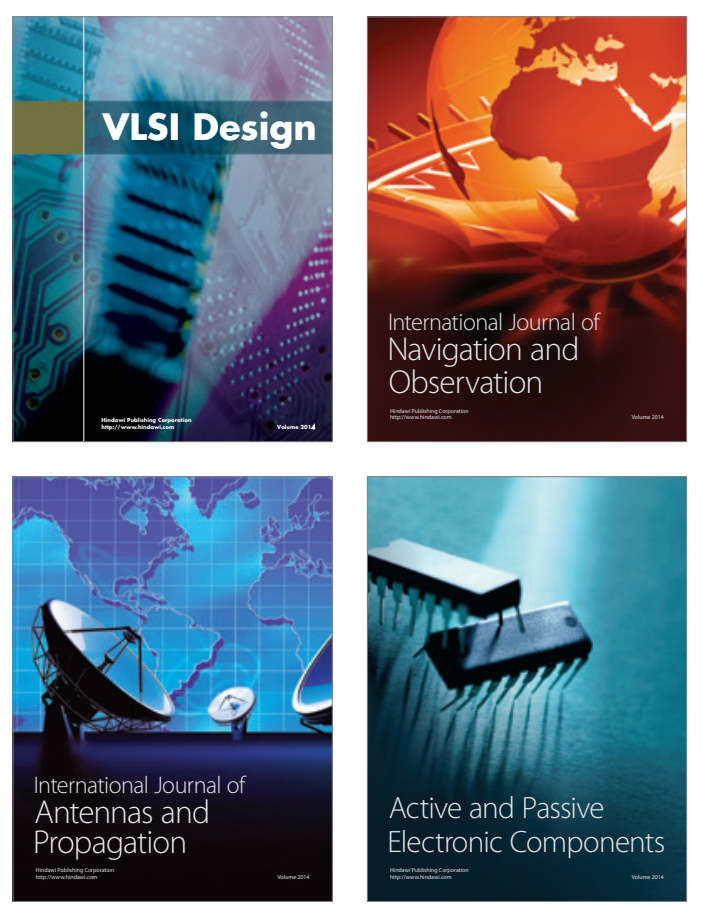
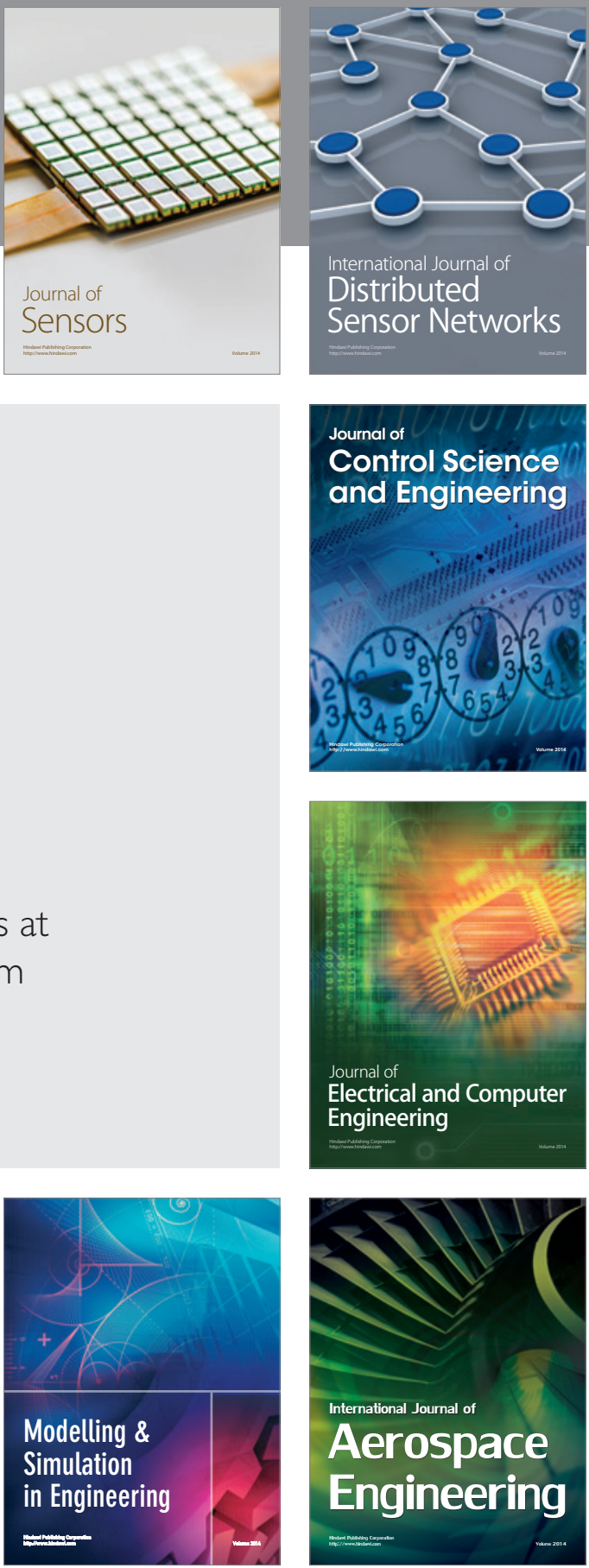

Journal of

Control Science

and Engineering
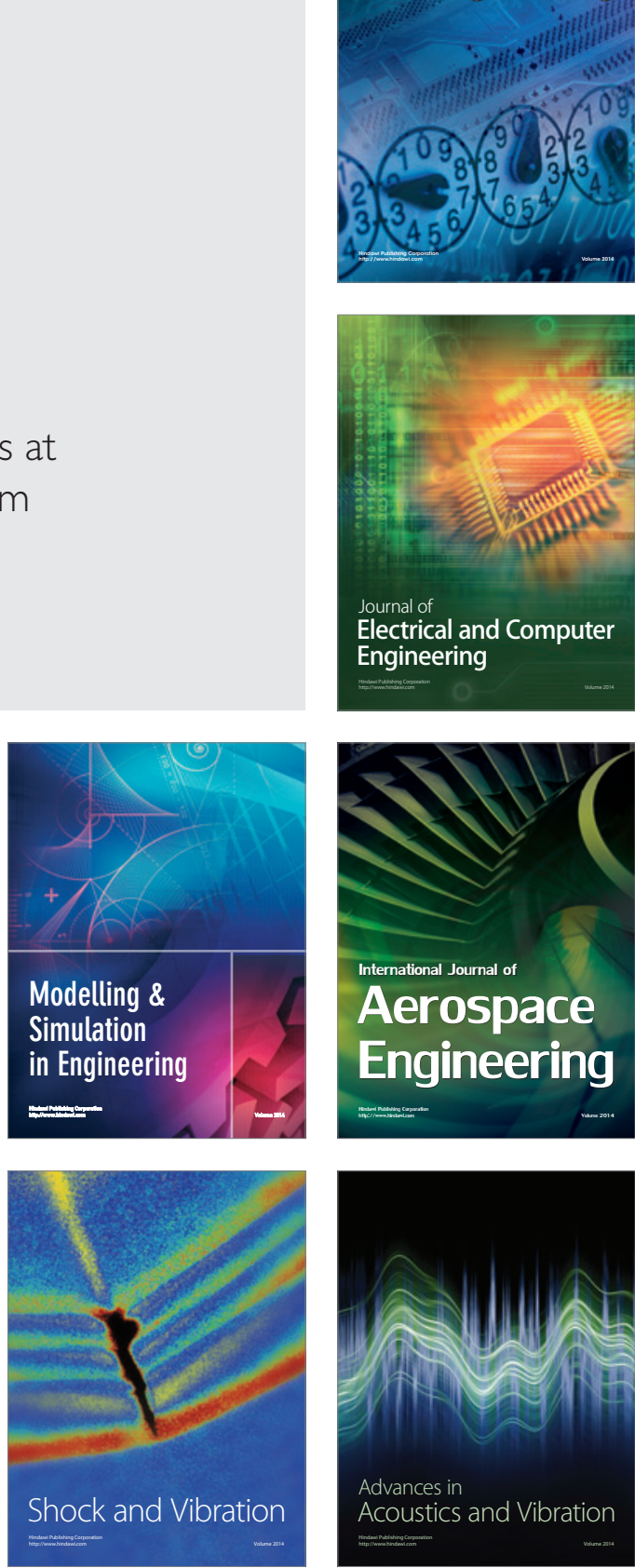